\title{
Study of Treatment Process Improvement of Fecal Sludge in Surabaya City and Optimization for The Retribution Management
}

\author{
Farid Pratama Putra, Eddy Setiadi Soedjono, and Ida Wahyuningsih \\ Department of Environmental Engineering, Institut Teknologi Sepuluh Nopember, Surabaya \\ e-mail: pratamafarid20@gmail.com
}

\begin{abstract}
IPLT Keputih is one and only fecal sludge treatment plant in Surabaya City. As mentioned on Perda No 1 Tahun 2016 Kota Surabaya, fecal sludge is one of the public services with current retribution cost of Rp. $15.000 / \mathrm{m} 3$. However, the retribution cost does not cover all fecal sludge treatment cost, rather merely as indicator for public participation to treat their fecal sludge. Throughout 2014-2018, the number of treated fecal sludge in IPLT Keputih is $134.537,52 \mathrm{~m} 3$ while the fecal sludge potential is up to $2.756 .146,5 \mathrm{~m} 3$. In order to increase public participation, it is necessary to review value and sytem of fecal sludge treatment and adjust it with local economic condition. In addition, to support the treatment potential, IPLT Keputih also needs some optimization in the retribution management. The method used in this study is started by collecting primary and secondary data about the treatment and retribution system. Laboratory test result will be the basic of process performance. After all data are complete, there will be some analysis based on the evaluation of process and operation, improvement process and operation recommendation based on process experiment, and retribution system optimization. To optimize the value of retribution and system, the optimal value of retribution and maximum service (treatment and desludging) is $\mathrm{Rp}$. 12.000/month combined with PDAM retribution. This will in return increase public participation in fecal sludge treatment.
\end{abstract}

Keywords-Fecal Sludge, IPLT Keputih, Retribution.

\section{INTRODUCTION}

$\mathrm{F}$ ECAL sludge contains various type of microorganism such as bacteria and virus, among others. The common concentration of fecal sludge is TSS $4.000-10.000 \mathrm{mg} / \mathrm{l}$, COD 5.000-80.000 mg/l, and BOD 2.000-30.000 mg/l. Therefore, fecal sludge needs proper treatment with liquid and solid separation principle. The treatment can be in physical, chemical, and biological form [1]. Fecal sludge emerges from on site sanitation technology that does not have adequate sewage system. Fecal sludge may contain solids, semi-solids, and liquid that is a combination of human excretion in the form of black water, with or without mix of grey water [2]. Fecal sludge has very high organic concentration. However, it also has high toxicity. The concentration of liquid in fecal sludge is $87,19 \%$ while the concentration of solid is $112,81 \%$ [3].

Sewage Treatment Plant (Instalasi Pengolahan Lumpur Tinja-IPLT) is a wastewater treatment plant designed to only receive and treat fecal sludge transported from fecal sludge trucks. Fecal sludge treatment in IPLT is an advanced treatment because fecal sludge from the septic tank is considered unfit to be dumped into environment [4] . According to (Anggraini, F., Effendi, R.R, 2014) the amount of IPLT in Indonesia is about 134 throughout the provinces with various condition.

IPLT Keputih is the only fecal treatment plant in Surabaya City, working under Agency of Sanitary and Green Open Space (Dinas Kebersihan dan Ruang Terbuka Hijau-DKRTH), built in 1991 with capacity of $400 \mathrm{~m}^{3} /$ day and filled capacity of 100 $\mathrm{m}^{3} /$ day. IPLT Keputih is designed to receive and treat fecal sludge transported through fecal sludge trucks [1]. Currently, IPLT Keputih has two trucks that provides desludging for city government buildings. On the other hand, IPLT Keputih also work with private companies for civilian property desludging [5]. IPLT Keputih contributes about $0,084 \%$ to the total regional retribution. It can be concluded that the ratio of sewage treatment retribution towards total income of regional retribution is still very low. The scale of current retribution amount for existing sewage treatment also shows the participation/contribution rate from Surabaya citizen in supporting good sanitation, especially in wastewater management.

In the future, in stabilizing financial independence of regional government as stated in Rencana Pembangunan Jangka Menengah Daerah Kota Surabaya (RPJMD) 2016-2021 in mission number 8, stabilizing good government management, Surabaya City Government (Pemerintah Kota Surabaya) needs to optimize incomes for locally generated revenue (Pendapatan Asli Daerah-PAD). Locally-generated revenue (PAD) is the regional income taxed through local regulation in accordance to Government Legislation [6]. Increasing of regional tax and retribution is one of the way regional government uses in order to increase locally generated revenue.

One thing to focus on as target market is the sewage treatment regulated in Peraturan Daerah Kota Surabaya No 1 Tahun 2016. The regulation states that the rate for retribution is Rp. $15.000 / \mathrm{m}^{3}$ with necessary assessment at least once every three years. 2019 has been marked three years since the regulation passed, hence assessment in regard of price index and economic development is necessary. This assessment will be legalized with Mayor Regulation (Peraturan WalikotaPerwali) regarding to the planned regulation for Scheduled 


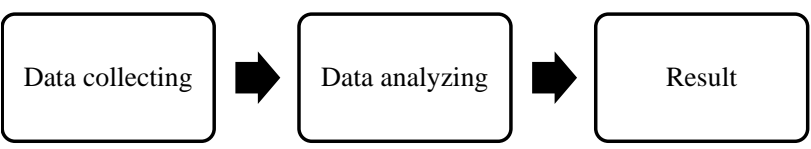

Figure 1. Step of Research.

Fecal Sludge Service (Layanan Lumpur Tinja TerjadwalLLTT) in Surabaya City. Therefore, preparation is necessary, such as process optimation with evaluating existing performance of IPLT Keputih to maximize its efficiency while preparing for legal documents. Retribution rate needs a reassessment appropriate with economic condition. Finalized legality regarding LLTT is expected to increase IPLT contribution in PAD.

\section{II.METHOD}

\section{A. Data Collection}

Primary and supporting data were gathered for this study. There were two kinds of data, which were primary and secondary data. Data was taken from field survey, interview, and laboratory observation by the author. The gathered data are as follow (1)Existing Condition of IPLT Keputih. Data regarding IPLT Keputih is shown on Table 1; (2)Interview Indepth interview is the chosen method with IPLT Keputih operator as the respondent and the question aims to gain comprehensive data and information regarding IPLT Keputih. The interview acts as reference to gather in-depth information.Interview detail: (a)Discussion regarding treatment system in IPLT Keputih with the workers; (b)Discussion regarding civilian property desludging with private companies; (c)Discussion regarding regulation.

\section{B. Retribution Value Calculation}

Retribution rate of fecal sludge treatment is calculated by summing the all cost regarding fecal sludge treatment and dividing it with treated fecal sludge volume [7].

$$
\text { Treatment }=\frac{\text { costbof fecal sludge treatment }}{\text { Treated fecal sludge volume }}
$$

Retribution rate of septic tank desludging is calculated by summing all cost regarding desludging and dividing it with transported fecal sludge volume [7].

$$
\text { Desludging }=\frac{\text { Cost of septic tank desludging }}{\text { Treated fecal sludge volume }}
$$

\section{C.Result}

Based on the data analizing for this research, so there will be taken some summary. Summary contains the simply answer from the goal of reseach. The research steps shown on figure 1.
Table 1.

\begin{tabular}{ll}
\multicolumn{1}{c}{ Data Information } \\
\hline \hline \multicolumn{1}{c}{ Data } & \multicolumn{1}{c}{ Data Function } \\
\hline Trend of fecal sludge inflow & $\begin{array}{l}\text { Information on existing sewage } \\
\text { treatment in IPLT Keputih as } \\
\text { reference to determine retribution } \\
\text { rate } \\
\text { Reference for fecal sludge inflow } \\
\text { projection } \\
\text { Information on the performance of } \\
\text { the existing process }\end{array}$ \\
$\begin{array}{ll}\text { Previous laboratory test data } \\
\text { Expenditure data for asset, } \\
\text { operational, employee salary, and } \\
\text { others regarding to the treatment }\end{array}$ & $\begin{array}{l}\text { Reference to determine retribution } \\
\text { rate }\end{array}$ \\
\hline \hline
\end{tabular}

Table 2.

Lists of Company Private

\begin{tabular}{ccc}
\hline \hline No & Company Name & Numbe of Truk \\
\hline 1 & AEF Jaya & 2 \\
2 & Anugerah & 2 \\
3 & Barokah & 3 \\
4 & Bima Sakti & 12 \\
5 & Cahaya Hidup & 1 \\
6 & Top & 4 \\
7 & Java Utama & 1 \\
8 & Jaya Abadi & 2 \\
9 & Kopsas & 1 \\
10 & Maju & 1 \\
11 & Mentari & 1 \\
12 & Mitra Abadi & 4 \\
13 & Nusa Jaya & 2 \\
14 & Prayogo & 1 \\
15 & Prima & 1 \\
16 & Sanjaya & 1 \\
17 & Setra Sari & 2 \\
18 & Sumber Jaya & 4 \\
19 & Sumber Kencono & 1 \\
20 & Sumber Rezeki & 3 \\
21 & Surya Agung & 3 \\
22 & Surya Kencana & 2 \\
23 & Sari Tinja & 1 \\
24 & Utama & 4 \\
25 & Tinja & 3 \\
26 & Wijaya & 2 \\
27 & Cahaya Cemerlang & 1 \\
28 & Eka Jaya & 1 \\
29 & Mitra Mandiri & 68 \\
\hline & Total & \\
\hline \hline
\end{tabular}

\section{RESULT AND DISCUSSION}

\section{A. Quantity of Existing Fecal Sludge}

IPLT Keputih receives fecal sludge from 29 private companies and 2 government issued trucks every day. List of company private is shown on Table 2. Desludging product from private companies usually come from commercial and noncommercial activities. Table 3 shows the quantity of fecal sludge 2014-2019. Currently, every cubic of sludge is charged retribution rate of Rp. 15.000 according to Pasal 14 Peraturan Daerah Kota Surabaya No 1 Tahun 2016. Government issued truck usually does desludging from government building in Surabaya City such as: (a)Culinary Center; (b)Flats (c)Market 
The $1^{\text {st }}$ International Conference on Business and Engineering Management (IConBEM 2020)

February $1^{\text {st }} 2020$, Institut Teknologi Sepuluh Nopember, Surabaya, Indonesia

Table 3.

Quantity of Fecal Sludge

\begin{tabular}{|c|c|c|c|c|c|c|c|c|c|c|c|c|c|}
\hline \multirow[t]{2}{*}{ Tahun } & \multicolumn{12}{|c|}{ 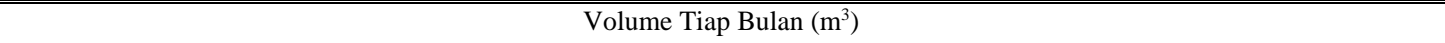 } & \multirow[t]{2}{*}{ Jumlah $\left(\mathrm{m}^{3}\right)$} \\
\hline & 1 & 2 & 3 & 4 & 5 & 6 & 7 & 8 & 9 & 10 & 11 & 12 & \\
\hline 2014 & 2345 & 2174,5 & 2893,5 & 2290,5 & 2424 & 2494,5 & 1980,5 & 2082 & 2217 & 1948 & 2014,5 & 2452 & 27316 \\
\hline 2015 & 2085,5 & 2253 & 2296,5 & 2082 & 2283,5 & 2311,5 & 2063 & 2574,5 & 2453,5 & 2619 & 2543 & 2337 & 27902 \\
\hline 2016 & 1809,5 & 1967,5 & 1999 & 1652,5 & 1617,5 & 1378 & 1154 & 3384,5 & 1750 & 1668,5 & 2604 & 2860,5 & 23845,5 \\
\hline 2017 & 2826,5 & 2424,5 & 2321 & 2215,5 & 2090 & 1854,5 & 2773,5 & 2620 & 2388,5 & 2607 & 2386,5 & 2235,5 & 28743 \\
\hline 2018 & 1972 & 2098,75 & 2514,66 & 2231,92 & 1904,82 & 1551,56 & 2388,14 & 2116,37 & 2253,9 & 2192,2 & 2685,8 & 2820,9 & 26731,02 \\
\hline 2019 & 2587,6 & 2434,4 & 2446,2 & 2303,8 & 2452,9 & 2254,6 & 3269,9 & 2754,1 & 2957,7 & 2947,8 & 3021,5 & 2828,2 & 32258,7 \\
\hline & & & & & & Jumlah & & & & & & & 166796,22 \\
\hline
\end{tabular}

Table 4.

Minimum Wage Increase in Surabaya City

\begin{tabular}{cccc}
\hline \hline & & \multicolumn{2}{c}{ Increase } \\
Year & Minimum Wage (Rp) & Rp & $\%$ \\
\hline 2014 & 2.200 .000 & 0 & 0 \\
2015 & 2.710 .000 & 510.000 & $23 \%$ \\
2016 & 3.045 .000 & 335.000 & $12 \%$ \\
2017 & 3.296 .212 & 251.212 & $8 \%$ \\
2018 & 3.583 .312 & 287.100 & $9 \%$ \\
2019 & 3.871 .052 & 287.740 & $8 \%$ \\
2020 & 4.200 .479 & 329.427 & $8 \%$ \\
\hline \hline
\end{tabular}

(d)Government Office; (e)Parks; (d)School; (f)Terminal

\section{B. Potential of Fecal Sludge Inflow}

According to data from Surabaya City Health Office (Dinas Kesehatan Kota Surabaya), in 2018 there were 77 urban village with ODF (Open Defecation Free) status. The amount of household with Open Defecation (Buang Air Besar Sembarangan-BABS) status was 336 households. There were 935.056 households with access to toilet with the following details: (1)863.306 households of permanent healthy toilet; (2)33.357 households of semi-permanent healthy toilet; (3)17.642 households using shared healthy toilet (SPALDS); (4)17.470 households using unhealthy toilet; (5)2.034 households using shared unhealthy toilet.Calculation for potential inflow of IPLT Keputih will use that data. Based on those typical conditions, potential fecal sludge comes from permanent healthy toilet, semipermanent healthy toilet, and shared healthy toilet. Technical calculation is as follow:

1) Potential of Permanent Healthy Toilet and Semi Permanent Healthy Toilet

Given:

Number of households $=896.663$

Septic Tank capacity $=3 \mathrm{~m}^{3}$

Desludging frequency = Every 3 years Thus,

Volume $=$ Number households $\mathrm{x}$ Septic Tank capacity

$$
\begin{aligned}
& =896.663 \times 3 \mathrm{~m}^{3} \\
& =2.689 .989 \mathrm{~m}^{3}
\end{aligned}
$$

Table 5.

Infrastructure and Facilities

\begin{tabular}{cl} 
& Infrastructure and Facilities \\
\hline \hline No & Infrastructure and Facilities \\
\hline 1 & Solid Separation Chamber \\
2 & Balancing Tank/Equalizer \\
3 & Oxidation Ditch \\
4 & Distribution Box \\
5 & Return Sludge \\
6 & Clarifier/Settling Tank \\
7 & Drying Bed \\
8 & Drying Area \\
9 & Alternative Sludge Treatment \\
10 & Sump Well \\
11 & Solvent from the River \\
12 & Polishing Pond \\
13 & Dump Truck \\
\hline \hline
\end{tabular}

Thus, the potential inflow of fecal sludge in IPLT Keputih from permanent healthy toilet and semi permanent healthy toilet is $2.689 .989 \mathrm{~m}^{3} / 3$ years.

2) Potential of Shared Healthy Toilet Given: 1 healthy toilet serves 4 households

Number of households $\quad=17.642 \mathrm{KK}$

Septic Tank capacity $=5 \mathrm{~m}^{3}$

Based on actual existing condition, healthy toilet usually desludge 1 time every year. Thus

$$
\begin{aligned}
\text { Volume } & =\frac{\text { Num household } x \text { Storage capacity }}{\text { Household num per toilet }} \\
\text { Volume } & =\frac{17.642 \times 5 \mathrm{~m}^{3}}{4} \\
& =22.052,5 \mathrm{~m}^{3} / \text { year }
\end{aligned}
$$

Thus, the potential desludging volume for IPLT Keputih from shared healthy toilet for 3 years is $66.157,5 \mathrm{~m}^{3} / 3$ years.

3) Amount of Desludging Truck

Therefore, the potential fecal sludge inflow volume in IPLT Keputih is 2.689.989 $\mathrm{m}^{3}+66.175,5 \mathrm{~m}^{3}=2.756 .146,5 \mathrm{~m}^{3} / 3$ years. Then, the calculation for required desludging truck is possible. Assumption: Daily routing is 4 route 1 truck has capacity of $3 \mathrm{~m}^{3}$. Workday is 7 days for 3 years for desludging The amount of required trucks:

$$
\begin{aligned}
\text { Num of truck } & =\frac{2.756 .146,5 \mathrm{~m}^{3}}{(365 \times 3) \text { day } \times 3 \mathrm{~m}^{3} \times 4 \frac{\text { route }}{\text { day }}} \\
& =210 \text { trucks }
\end{aligned}
$$


The $1^{\text {st }}$ International Conference on Business and Engineering Management (IConBEM 2020)

February $1^{\text {st }} 2020$, Institut Teknologi Sepuluh Nopember, Surabaya, Indonesia

Table 6. Cost to Treat Fecal Sludge

\begin{tabular}{clc}
\hline \hline No & \multicolumn{1}{c}{ Items } & Total (Rp) \\
\hline 1 & Employees Expendeture (2014-2019) & 2.409 .365 .455 \\
2 & Operational and maintenance (2014) & 1.548 .539 .472 \\
3 & Operational and maintenance (2015) & 1.480 .088 .007 \\
4 & Operational and maintenance (2016) & 1.591 .508 .061 \\
5 & Operational and maintenance (2017) & 2.155 .178 .777 \\
6 & Operational and maintenance (2018) & 2.082 .881 .190 \\
7 & Operational and maintenance (2019) & 1.115 .217 .517 \\
8 & Budget for infrastructure (2014-2019) & 2.461 .095 .653 \\
9 & Process improvement (2020) & 25.640 .000 \\
\hline Total & \multicolumn{2}{c}{14.869 .514 .130} \\
\hline \hline
\end{tabular}

In order to realize LLTP program, 210 unit of trucks is required. Upon realization, Surabaya City will have full service in 3 years.

\section{Retribution Rate Evaluation}

Evaluation of fecal sludge treatment retribution rate uses secondary data from the last 5 years. The process to calculate retribution rate of sewage treatment in the form of fecal sludge is as follows: (1)Identify and calculate the increase/decrease of the macro indicator of Surabaya City, as in inflation and population. There is a positive trend in economic development that indicates the increase of people's purchasing power. The minimum wage for Surabaya City keeps increasing from 2014 to 2019. There has been increase of Rp. 1.671.052,00 from the minimum wage of Rp. 2.200.000,00 in 2014 to Rp. $3.871 .052,00$ in 2019 , which is a $75,96 \%$ increase. To increase service quality of sewage treatment towards the citizen, there has been innovation of technologies for wastewater treatment that makes it also go up in cost. Increase of minimum wage in Surabaya City is shown on Table 4;(2)Identify required infrastructure and facilities to treat wastewater in the form of fecal sludge. Required infrastructure and facilities to treat wastewater in the form of fecal sludge and non-fecal sludge includes all installation, tools, and materials used as well as the workers involved in the service of fecal sludge treatment. Broadly, the required infrastructure and facilities for fecal sludge treatment is shown in Table 5;(3)Calculating fecal sludge treatable with existing infrastructure and facilities . In order to calculate service unit cost of sewage treatment service, it is necessary to calculate the fecal sludge that is treatable with existing infrastructure and facilities. Based on potential studies of wastewater retribution, the volume of fecal sludge in IPLT fluctuated each year. In 2014, the volume of fecal sludge dumped to IPLT was $27.316,00 \mathrm{~m}^{3}$ and 27.902,00 $\mathrm{m}^{3}$ in 2015. In 2016, it decreased significantly into $23.845,50 \mathrm{~m}^{3}$ per year. The next year, 2017, it went back up into $28.743,00 \mathrm{~m}^{3}$. The volume of fecal sludge in 2018 was $26.731,02 \mathrm{~m}^{3}$ making the total volume of fecal sludge from 2014 to 2018 was 134.537,52 $\mathrm{m}^{3}$;(4)Calculating total cost to treat fecal sludge wastewater. The next step is calculating total cost to treat fecal sludge wastewater. Total Cost includes the whole plant, mechanism, and materials used as well as workers involved in the service. The cost can be seen in Table 6;(5)Calculating retribution rate for fecal sludge wastewater treatment. The last step is
Teble 7.

Retribution Potential

\begin{tabular}{ccccc}
\hline \hline \% Unit Cost & Unit Cost $(\mathrm{Rp})$ & Tarif $(\mathrm{Rp})$ & Volume $\left(\mathrm{m}^{3}\right)$ & PAD Potency (Rp) \\
\hline $100 \%$ & 89.331 & 89.331 & 32.258 & 2.881 .639 .398 \\
$50 \%$ & 89.331 & 44.666 & 32.258 & $1,440.819 .699$ \\
$30 \%$ & 89.331 & 26.799 & 32.258 & 864.491 .819 \\
\hline \hline
\end{tabular}

Table 8.

Cost of Infrastructure and Facilities for 1 Year Desludging

\begin{tabular}{lcc}
\hline \hline Infrastructure and Facilities & Unit Cost (Rp) & Total (Rp) \\
\hline Desludging Truck (210) & 484.682 .500 & 101.741 .325 .000 \\
Support Facilities & 72.000 .000 & 72.000 .000 \\
Fuel & 1.502 & 2.523 .360 .000 \\
Employee (2 people for 1 & 11.400 .000 & 1.596 .000 .000 \\
truck) & \multicolumn{2}{c}{105.932 .685 .000} \\
\hline \multicolumn{1}{c}{ Total } &
\end{tabular}

calculating the retribution rate of fecal sludge wastewater treatment. To calculate the rate, the unit cost must be calculated first. Unit cost is calculated with the following formula:Based on the data in Table 6, it is known that the total cost to provide sewage treatment is Rp. 14.528.656.615. Based on the calculation, it is known that the treatable fecal sludge in IPLT is $166.796,22 \mathrm{~m}^{3}$. According to those data, the unit cost is calculable as follows:

$$
\begin{aligned}
\text { Treatment Retribution } & =\frac{\text { Sewate treatment cost }}{\text { Treated sludge volume }} \\
& =\frac{R p .14 .896 .514 .130}{166.796,22 \mathrm{~m}^{3}} \\
& =\text { Rp. } 89.331 / \mathrm{m}^{3}
\end{aligned}
$$

In conclusion, the retribution rate for sewage treatment in 20142019 was Rp. $89.331 / \mathrm{m}^{3}$.

\section{D.Recommendation for Retribution Optimization}

The target of this retribution optimalization of sewage treatment is to provide maximum service with optimum retribution rate. All this time, the retribution from sewage treatment is relatively small in PAD income. It also shows citizen's partiality in participating with desludging their septic tank. Higher retribution rate means higher contribution rate. Even so, retribution value from sewage treatment service will not cover all cost of the sewage treatment itself. This is because the released retribution rate is subsidized instead of being the actual calculation. In the future, the potential fecal sludge volume to be treated in IPLT Keputih based on technical calculation is $2.756 .146,5 \mathrm{~m}^{3} / 3$ years. The next step is to determine alternative retribution rate based on the calculation. The alternative rate consists of 3 types of rate, which are:

$$
\text { a. } \begin{aligned}
& \text { Covering } 100 \% \text { Unit Cost } \\
& \text { Rate }=100 \% \times \text { Unit Cost } \\
&=100 \% \times \text { Rp. } 89.331 \\
&=\text { Rp. } 89.331
\end{aligned}
$$

b. Covering $50 \%$ Unit Cost

Rate $=50 \% \times$ Unit Cost 
The $1^{\text {st }}$ International Conference on Business and Engineering Management (IConBEM 2020)

February $1^{\text {st }} 2020$, Institut Teknologi Sepuluh Nopember, Surabaya, Indonesia

$$
\begin{aligned}
& =50 \% \times \text { Rp. } 89.331 \\
& =\text { Rp. } 44.665
\end{aligned}
$$

c. Covering $30 \%$ Unit Cost

Rate $=30 \% \times$ Unit Cost

$=30 \%$ x Rp. 89.331

= Rp. 26.799

City Government previously aimed Rp. 590.000 .000 retribution value from sewage treatment each year. This target has never been achieved before, with the highest income reaching $90 \%$ of it. Therefore, the treatment rate is Rp. 26.799 for every $\mathrm{m}^{3}$ of waste. It must be noted that the principle of sewage treatment is that of public service, therefore it is not allowed to overly burden the citizen. Thus, the most possible alternative rate is the $30 \%$ coverage of unit cost, making the rate become $\mathrm{Rp} .26 .799 / \mathrm{m}^{3}$. This rate is increasing from the initial rate of $\mathrm{Rp}$. 15.000. With this rate, it is possible to accomplish the retribution target. The target of retribution optimalization is to create a condition where the rate of retribution is optimum with maximum service of treatment. The Retribution Potential is shown in Table 7, the citizens need to be assured that the retribution rate charged to them is not overly burdening. Sewage treatment retribution can't cover treatment cost, instead only showing the citizen participation factor. Therefore, with a reasonable rate, larger part of the citizen is expected to join the system. On the other hand, city government can still provide maximum service because the cost is covered by retribution from another aspect. To ease citizen in retribution payment, a desludging schedule can gradually be issued according to the infrastructure and facilities. Therefore, calculation of desludging cost is necessary. Periodical desludging is scheduled for 3 years. The calculation uses the following steps; (1)Identify infrastructure and facilities. The required infrastructures and facilities based on the calculation are 210 desludging truck, support facilities, employee salary, and fuel. The operational cost of desludging based on DKRTH is shown in Table 8.

Cost of desludging truck

Cost of support facilities

Cost of fuel

= Rp. 484.682.500/ unit

= Rp. $72.000 .000 /$ year

$=1.501,78 \mathrm{~L} /$ year

Employee salary = Rp. $3.800 .000 /$ person month $\mathrm{x} 3$ people

= Rp. $11.400 .000 /$ month; (2)Identify the Potential of Fecal

Sludge Inflow.Based on probability calculation, in 3 years there could be 2.756.146,5 $\mathrm{m}^{3}$ inflow of fecal sludge. Thus, for 1 year, the potential inflow is $918.715,5 \mathrm{~m}^{3}$; (3)Calculating Desludging Cost.

Desludging Retribution $=\frac{\text { Inf \& fac total cost }}{\text { Fecal Sludge Potential }}$

$$
\begin{aligned}
& =\frac{R p .105 .932 .685 .000}{m^{3}} \\
& =\text { Rp. } 115.305 / \mathrm{m}^{3}
\end{aligned}
$$

Then, the treatment cost with $30 \%$ unit cost is added with the desludging cost: Rp. 26.799 + Rp. 115.305 = Rp. 142.104 rounding down to Rp. $142.000 / \mathrm{m}^{3}$. Assuming the desludging volume is $3 \mathrm{~m}^{3}$ and the scheduling is 3 years, the monthly retribution charged to the citizen is:

$$
\begin{aligned}
\text { Monthly Cost } & =\frac{\text { Cost of treatment and desludging } 3 \mathrm{~m}^{3}}{3 \text { years } x 12 \frac{\text { months }}{\text { year }}} \\
& =\frac{\text { Rp. } 426.000}{3 \text { years } x 12 \frac{\text { month }}{\text { year }}} \\
& =\text { Rp. } 11.833 / \text { month } \\
& =\text { Rp. } 12.000 / \text { month (rounding up) }
\end{aligned}
$$

The following are some possible payment methods for the sewage treatment service: (1)Combined with solid waste retribution. The advantage of combining the sewage retribution with solid waste service is the regulation that states that those who are obligated to pay solid waste retribution are: those who have not registered in Water Municipal Service (Perusahaan Daerah Air Minum-PDAM), those who registered to PDAM and produce more than $1 \mathrm{~m}^{3} /$ day solid waste, and those who registered to PDAM and dump solid waste directly to landfill (Tempat Pembuangan Akhir-TPA). Solid waste treatment executed by DKRTH has achieved $96,43 \%$ of all solid waste in Surabaya City in 2018. This shows that citizen participation will be easy to obtain. The weakness of this system is the too much rate classification in the City Government Regulation. In the attachment of Perda Nomor 10 Tahun 2012, there are 6 classifications in which there are numerous criteria in each classification. Other than that, the existing condition of solid waste treatment in Surabaya is not yet optimum, especially regarding the retribution payment; (2)Combined with PDAM retribution. The advantage of this system is that the amount of PDAM user in Surabaya City shows as many as 567.819 connections in 2018 according to Surabaya City PDAM official website. PDAM system that gives penalty for lateness in payment by stopping access is also a consideration in determining the method. Applying proper LLTT system, operator institution with adequate technical and managerial capacity is necessary. For now, there is no other city level institution with the capacity to handle tens of thousands of customers aside from PDAM - The weakness of this system is the fluctuative cost of PDAM that makes people tend to complain on peak usage. Another weakness is the need to alter the local regulation regarding PDAM institution if PDAM is to be involved as LLTT operator; (3)Direct billing to each households through hamlet-neighborhood-urban village. The advantage of this system is a more organized billing system, starting from hamlet level to neighborhood level, urban village, and keep going up PAD. The weakness of this system is the different condition in each area makes billing condition unreliable. Some will be cooperative; the other will be difficult, and so on; (4)Directly managed by IPLT Keputih. This last option is a projection for long term application because IPLT Keputih needs to achieve some institutional option to make it happen. In order to be LLTT operator, IPLT Keputih must be a Technical Implementation Unit (Unit Pelaksana Teknis-UPT) or Local Company (Perusahaan Daerah-PD). UPT is often considered more apt for initial running of LLTT. As part of Regional Work Unit (Satuan Kerja Perangkat Daerah-SKPD) 
above UPT, its operational will be funded by city government. Direct management will ease work management when new regulation is formed. However, currently IPLT Keputih is under DKRTH, therefore, this alternative is difficult to apply. IPLT Keputih still needs a lot of changes and better system arrangement especially regarding desludging system. The most effective method for Surabaya City is the second method, which is combined retribution with PDAM. Some region like Surakarta and Sibolga have applied this system. Fecal sludge retribution is quite big, but in monthly installment for LLTT target in 3 years, the citizen will be more at ease. If a PDAM has high drinking water service area (at least 60\%), it is eligible as LLTT operator. Some PDAM has used modern information technology. Appointing PDAM as the LLTP operator will also combine LLTT financial account with drinking water service account. Every month, PDAM user will only receive one billing with a certain amount consisting of drinking water bill and LLTT bill. With this combined system, paying LLTT bill is imperative to get drinking water service. This forcing power will increase efficiency of LLTT payment [8]. PDAM Surabaya is already appropriate to be LLTT operator because it has high service percentage. In addition, Surabaya City PDAM has good service quality, according to its satisfactory handling of customer complaint [9]. If IPLT Keputih, with its current system of on call service, changes into UPT or PD, then it can handle its own retribution billing system. Consequently, there will be a new system to manage sewage treatment in Surabaya City. Even though it needs a lot of time and energy, this new system can be designed to adjust its service and create momentum to revitalize sanitation.

\section{CONCLUTION}

The real value of sewage treatment retribution is $\mathrm{Rp}$. $89.331 / \mathrm{m}^{3}$. The optimum retribution billing system for
Surabaya City is by combining sewage treatment retribution rate into PDAM retribution rate by adding treatment rate and desludging rate, thus the citizen will need to pay Rp. $12.000 /$ month. However, this retribution value is not the core for PAD, but only as an indicator to show people's participation in treating fecal sludge.

\section{V.ACKNOWLEDGEMENTS}

Special thanks for the management of IPLT Keputih who has given permission and provided the necessary data to the authors so this research can be carried out properly.

\section{REFERENCES}

[1] G. D. Mega and W. Herumurti, "Evaluasi kinerja instalasi pengolahan lumpur tinja (iplt) keputih, surabaya,” J. Tek. ITS, vol. 5, no. 1, pp. 1-6, 2016, doi: 10.12962/j23373539.v5i1.15035.

[2] D. Strande, L., Ronteltap, M., Brdjanovic, Fecal Sludge Management System Approach for Implementation and Operation. London: IWA Publishing, 2014.

[3] D. R. Lestari and G. Yudihanto, "Pengolahan lumpur tinja pada sludge drying bed iplt keputih menjadi bahan bakar alternatif dengan metode biodrying,” Institut Teknologi Sepuluh Nopember Surabaya, 2013.

[4] H. Oktarina, D., Haki, "Perencanaan instalasi pengolahan lumpur tinja sistem kolam kota palembang (studi kasus iplt sukawiatan)," J. Tek. Sipil dan Lingkung., vol. 1, no. 1, pp. 74-79, 2013.

[5] A. W. Pamungkas and A. Slamet, "Pengolahan tipikal instalasi pengolahan air limbah industri tahu di kota surabaya," J. Tek. ITS, vol. 6, no. 2, 2017, doi: 10.12962/j23373539.v6i2.24585.

[6] Imellia and F. Ananda, "Analisis kinerja juru pungut retribusi pelayanan persampahan terhadap target retribusi pelayanan persampahan pada dinas lingkungan hidup kota padang," STIE Keuangan Perbankan dan Pembangunan, 2006.

[7] A. Halim, Akuntansi Keuangan Daerah. Jakarta: Salemba Empat, 2008.

[8] USAID, Layanan Lumpur Tinja Terjadwal. Washington: United States Agency for International Development, 2016.

[9] D. J. Kuncoro, "Studi deskriptif tentang kualitas pelayanan penanganan keluhan pelanggan perusahaan daerah air minum kota surabaya," $J$. Kebijak. dan Manaj. Publik 4(2). Surabaya, 2016. 